\title{
Detection of antibiotic resistance genes in Lactobacillus and its role in transferring these genes to Salmonella
}

\author{
Muhammad Ashraf, Sidra Anam*, Faisal Rasheed Anjum, Sultan Ali \\ and Rizwan Aslam \\ Institute of Microbiology, Faculty of Veterinary Science, University of Agriculture, Faisalabad-Pakistan \\ *Corresponding author's email: sidraanam2924@gmail.com \\ Citation \\ Muhammad Ashraf, Sidra Anam, Faisal Rasheed Anjum, Sultan Ali and Rizwan Aslam. Detection of antibiotic \\ resistance genes in Lactobacillus and its role in transferring these genes to Salmonella. Pure and Applied Biology. \\ Vol. 8, Issue 3, pp2007-2014. http://dx.doi.org/10.19045/bspab.2019.80145
}

Received: $21 / 04 / 201$

Revised: 09/07/2019

Accepted: 16/07/2019

Online First: 24/07/2019

\section{Abstract}

Antibiotic resistance is a worldwide issue and becoming problematic due to extensive misuse of antibiotics. The present study was aimed to analyze the role of Lactobacillus in transmission of antibiotic resistance genes (tet $\mathrm{M}, \operatorname{erm} \mathrm{B}, \mathrm{sul} 2)$ to Slamonella and verification of these genes by quantitative polymerase chain reaction. A total of thirty fecal samples (15 were indigenous and 15 were broilers) were collected and genomic DNA was isolated. Both Salmonella and Lactobacillus were confirmed by polymerase chain reaction. The expression and quantification of antibiotic resistance genes was done by quantitative polymerase chain reaction. The results indicated that there was higher expression of antibiotic resistance genes in Lactobacillus isolated from broiler chicken than the isolates obtained from indigenous birds indicating Lactobacillus as a reservoir of antibiotic resistance genes. But the role in transferring these genes to Salmonella was found to be non-significant. In conclusion, the excessive use of animal growth promoters in poultry assists in acquisition of antibiotic resistance by Lactobacillus and contributes in spread of antibiotic resistant determinants.

Keywords: Antibiotics; Determinants; Quantitative polymerase chain reaction

\section{Introduction}

Salmonella enterica is a zoonotic pathogen and transfers from animal to humans with the consumption of animal products, contaminated meat, or other contaminated food products [1]. It has been reported that about 1,335 foodborne outbreaks and 36,490 foods related illnesses occur due to Salmonella enterica [2]. Tetracycline resistance in Salmonella is attributed due the efflux pump that expels out tetracycline from the cell [3].Whereas resistance against sulfonamide in Salmonella has been recognized due to the presence of sul gene which states an insensitive type of dihydrofolatesynthetase[4].

Antibiotic resistance is a global issue and because of this, bacteria are becoming more resistant against antibiotics by developing different mechanisms of antibiotic resistance like: enzymatic degradation, target modification and target substitution [5]. This could either be due to mutation or acquirement of a particular antibiotic 
resistance (AR) gene by horizontal transfer [6]. The accessibility of antibiotics to be used for treatment of infectious diseases has considerably improved the human health and animal welfare. But massive misuse of antibiotics causes the development of antimicrobial resistance in commensals and pathogenic bacteria [7].

Lactobacillus species isolated from meat and fermented milk products have offered resistance to tetracycline, vancomycin and erythromycin [8]. In pathogenic or commensals strains, AR genes produce an indirect risk for animals and humans and as well as the enlargement of gene pool for different other pathogenic and exogenous bacteria to grab them to advance antibiotic resistance. There are multiple pathways of antibiotic resistance gene transfer including conjugation and transformation as well as transduction. Horizontal gene transfer (HGT) of antimicrobial resistance genes is significantly enhanced by plasmids, transposons and integrons [9]. The AR genes frequently exist on mobile elements like integrons, plasmids and transposons [10].

It has been reported that possible increase of resistance happened because of excessive use of antibiotics [11]. The incidence of AR genes; $\operatorname{erm}(\mathrm{B})$ and $\operatorname{tet}(\mathrm{M})$ for erythromycin and tetracycline respectively in Lactobacilli represents the most pervasive determinant of resistance. Moreover, in genetic linkage of Lactobacillus paracasei, both these genes were frequently stated [12]. The current study is intended for the evaluation of Lactobacillus role in transmitting AR genes to Salmonella.

\section{Materials and methods}

The following research was conducted in Institute of Microbiology University of agriculture, Faisalabad. A total of fifteen samples were taken from three indigenous poultry birds (5 samples from each chicken) and fifteen samples from three broiler birds (5 samples from each chicken). Total thirty fecal samples were taken from the colon region of birds for the isolation of Lactobacillus and Salmonella. Bead containing collection tubes were used for the collection of all the samples. FavorPrep Stool DNA Isolation Mini Kit was used for genomic DNA isolation following the protocol described [13].

\section{Nano-quantification of extracted DNA}

With the help of Nano drop, exact DNA concentration was assessed using 1000 spectrophotometer Thermo scientific $®$. For this objective, $1 \mu \mathrm{L}$ of freshly extracted DNA was taken and released on thepointed surface of sterilized and specialized Nano spectrophotometer, which provided the accurate concentration of DNA along with the 260/280 and 260/230 values [14].

\section{PCR Detection of Lactobacillus and Salmonella}

Lactobacillus and Salmonellae were detected by PCR amplification of DNA samples using primers

(LAA;

F:CATCCAGTGCAAACCTAAGAG, R:GATCCGCTTGCCTTCGCA [15] \& InvA; F:CGGTGGTTTTAAGCGTACTCTT, R:CGAATATGCTCCACAAGGTTA) respectively by using 16 SrRNA micro processed controlled swift Maxi thermal cycler block (Esco technologies Inc. France). In negative control, no sample was loaded.The amplified products were then visualized on $1 \%$ agarose gel [17].

Quantitative Polymerase Chain Reaction (qPCR) for detection of tetM, ermB and Sul2 genes

The qPCR also called real time polymerase chain reaction (RT-PCR) analysis was used for the verification of the results that were found from the analysis of Microarray. For this purpose, steps described by [18] were followed. Briefly, genomic DNA up to $20 \mathrm{ng} / \mu \mathrm{L}$ was required for each reaction and primers (Table 1) [19] were purchased from Thermo Fisher Scientific and were used by dilution at a ratio of 1:20 from a solution of $5 \mu \mathrm{M}$. For each reaction, Master Mix of $5 \mu \mathrm{L}$ 
Dynamo Flash and ROX up to $0.25 \mu$ Lwas added into each valve. After that, $10 \mu \mathrm{L}$ of high performance liquid chromatography (HPLC) water was added and mixed reaction mixer was used for qPCR. The thermal cycler conditions and the reaction mixture's composition is given in (Table $2 \& 3$ ).

\section{Expression of qPCR data}

Absolute gene copy number was expressed as the no. of copies of resistant genes (reference florescent unit RFU) during each cycle. Absolute abundance was calculated based on the results obtained for the corresponding standard of each resistant gene. Relative abundance was calculated using $\mathrm{E}=10^{-}$ $1 /$ slope . From this, the ratio of the relative expression of the targeted gene to reference gene (Rpl32) was calculated as follows; $\Delta \mathrm{Ct}$ $=\mathrm{Ct}$ target $-\mathrm{Ct}$ reference $(\Delta \mathrm{Ct}$ : change of the cycle threshold $(\mathrm{Ct})$ that was calculated during the amplification).

\section{Results and discussion}

This study was aimed to detect antibiotic resistance genes in Lactobacillus and its role in transmission of these genes to Salmonella. The detection of Lactobacillus was done by presence of LAA gene consisting of $250 \mathrm{bp}$ (Fig.1) while appearance of 796bp band yielded from Inv-A primer amplification confirmed the presence of Salmonella (Fig.2).

The qPCR expression of tet $\mathrm{M}$ demonstrated that the expression of tet $\mathrm{M}$ in Lactobacillus in case of broiler chicken sample was higher as compared to its expression in Salmonella isolated from indigenous chickens representing the role of Lactobacillus as a reservoir of tet $\mathrm{M}$ gene. The $\mathrm{qPCR}$ results are also indicating the higher expression of tet $\mathrm{M}$ gene in broiler as compared to indigenous chickens which may be due to the excessive use of antibiotic growth promoters in broiler chickens (Fig. 3 \& Table 4). The results of qPCR for erm $\mathrm{B}$ gene showed the expression of this gene in Lactobacillus and Salmonella isolated from indigenous and broiler chicken samples indicating Lactobacillus as a reservoir for $e r m \mathrm{~B}$ gene. The transfer of these genes to Salmonella has been found to be non-significant due to low erm $\mathrm{B}$ gene expression in Salmonella isolated from broiler and indigenous chickens (Fig. 4 \& Table 5). The sul2results revealed its expression in Lactobacillus and salmonella in indigenous as well as in broiler chickens. The high expression of sul2 gene in Lactobacillus of broiler chickens indicates that Lactobacillus in broiler chickens serves as a reservoir for sul2 gene (Fig. 5 \& Table 6). The analysis of $\mathrm{Ct}$ values for different $\mathrm{AR}$ genes in $\mathrm{qPCR}$ represents that tet $\mathrm{M}$ gene is showing the highest expression among the three antibiotic resistance genes. It was found that the most frequent antibiotic resistance gene was tet $\mathrm{M}$ followed by ermB and $s u l 2$. The qPCR results of present study exhibited that Lactobacillus isolated from broiler chickens serves as a reservoir of antibiotic resistance genes due to presence and higher expression level of AR genes (tet $\mathrm{M}$, sul 2 and erm $\mathrm{B})$. The transmission of antibiotic resistance genes to Salmonella in present study was found to be non-significant because of the very low $\mathrm{Ct}$ values and low expression of antibiotic resistance genes in Lactobacillusisolated from indigenous chicken samples and in Salmonella isolated from both indigenous and broiler chicken specimens. Similar work was performed by [20] who detected tetracycline resistant gene (tet $\mathrm{M})$ from Lactobacillus isolates. Other researchers [21] also worked on detection of antibiotic resistance pattern mediated by tet $\mathrm{M}$ and tet $\mathrm{L}$ genes in different Enterococcus bacteria. Another study [22] investigated susceptibility of Lactobacillus paracasei to tetracycline and erythromycin and found that this bacterium may act as reservoir for transferring antibiotic resistance genes to other pathogenic bacteria. In another report [23], erm $\mathrm{B}$ and tet $\mathrm{M}$ genes were detected from different lactic acid bacterial isolates of 
fermented foods. The study done by $[24,25]$ closely match to our present study who investigated the role of Lactobacillus species in transferring tet $\mathrm{M}$ and erm $\mathrm{B}$ genes to other Enterococcus species. The results of the present research also closely relate to the previous research done by [26] who investigated the role of antibiotic growth promoters in the acquisition of antibiotic resistance genes in commensals and pathogenic bacteria to develop antibiotic resistance.

Table 1. Primers for Erythromycin erm(B), Sulfonamide (sul2), Tetracycline tet(M) antibiotic resistance genes

\begin{tabular}{|c|c|}
\hline Genes & PrimersSequences (5'-3') \\
\hline ermB & $\begin{array}{l}\text { F: TGGTATTCCAAATGCGTAATG } \\
\text { R: CTGTGGTATGGCGGGTAAGT } \\
\text { (Zhang } \text { et al., 2011) }\end{array}$ \\
\hline sul2 & $\begin{array}{c}\text { F: GCAGGCGCGTAAGCTGA } \\
\text { R: GGCTCGTGTGTGCGGATG } \\
\text { (Zhang } \text { et al., 2011) }\end{array}$ \\
\hline tet $\mathrm{M}$ & $\begin{array}{c}\text { F:CGAACAAGAGGAAAGCATAAG } \\
\text { R: CAATACAATAGGAGCAAGC } \\
\text { (Zhang } \text { et al., 2011) }\end{array}$ \\
\hline
\end{tabular}

Table 2. PCR Components and their concentration

\begin{tabular}{|c|c|c|c|}
\hline S. No. & Component & Quantity & Concentration \\
\hline 1 & $\mathrm{MgCl} 2$ & $1.5 \mu \mathrm{L}$ & $5 \mathrm{mM}$ \\
\hline 2 & $10 \mathrm{x}$ buffer & $3 \mu \mathrm{L}$ & $\ldots$ \\
\hline 3 & Primer R & $1 \mu \mathrm{L}$ & $10 \mathrm{pmol}$ \\
\hline 4 & Primer F & $1 \mu \mathrm{L}$ & $10 \mathrm{pmol}$ \\
\hline 5 & RNA-free water & $14.3 \mu \mathrm{L}$ & $\ldots$ \\
\hline 6 & dNTPS & $1 \mu \mathrm{L}$ & $200 \mu \mathrm{M}$ \\
\hline 7 & Template DNA & $3 \mu \mathrm{L}$ & $50 \mathrm{ng}$ \\
\hline 8 & Taq polymerase & $0.2 \mu \mathrm{L}$ & $5 \mathrm{U}$ \\
\hline & Total & $25 \mu \mathrm{L}$ & \\
\hline
\end{tabular}

Table 3. Thermo-cycler conditions for DNA AmplificationCycling 34 repeats

\begin{tabular}{|c|l|r|}
\hline Initial denaturation & $\mathbf{9 4}^{\circ} \mathbf{C}$ & $\mathbf{5 ~ m i n}$ \\
\hline Denaturation & $94^{\circ} \mathrm{C}$ & $60 \mathrm{sec}$ \\
\hline Annealing & $58^{\circ} \mathrm{C}$ & $30 \mathrm{sec}$ \\
\hline Extension & $72^{\circ} \mathrm{C}$ & $2 \mathrm{~min} 30 \mathrm{sec}$ \\
\hline Final extension & $72^{\circ} \mathrm{C}$ & $5 \mathrm{~min}$ \\
\hline
\end{tabular}

Table 4. Ct values of tetM gene in Lactobacillus, Salmonella(isolated from both Indigenous and Broiler samples)

\begin{tabular}{|c|c|c|}
\hline & Indigenous & Broiler \\
\hline Lactobacillus & 0.0315 & 5.16 \\
\hline Salmonella & 0.00385 & 0.0039 \\
\hline
\end{tabular}


Table 5. Ct values of ermB gene in Lactobacillus, Salmonella (isolated from both Indigenous and Broiler samples

\begin{tabular}{|c|c|c|}
\hline & Indigenous & Broiler \\
\hline Lactobacillus & 0.0155 & 4.18 \\
\hline Salmonella & 0.00495 & 0.0083 \\
\hline
\end{tabular}

Table 6. Ct values of sul2 gene in Lactobacillus, Salmonella (isolated from both Indigenous and Broiler samples)

\begin{tabular}{|c|c|c|}
\hline & Indigenous & Broiler \\
\hline Lactobacillus & 0.0265 & 3.06 \\
\hline Salmonella & 0.00155 & 0.006 \\
\hline
\end{tabular}

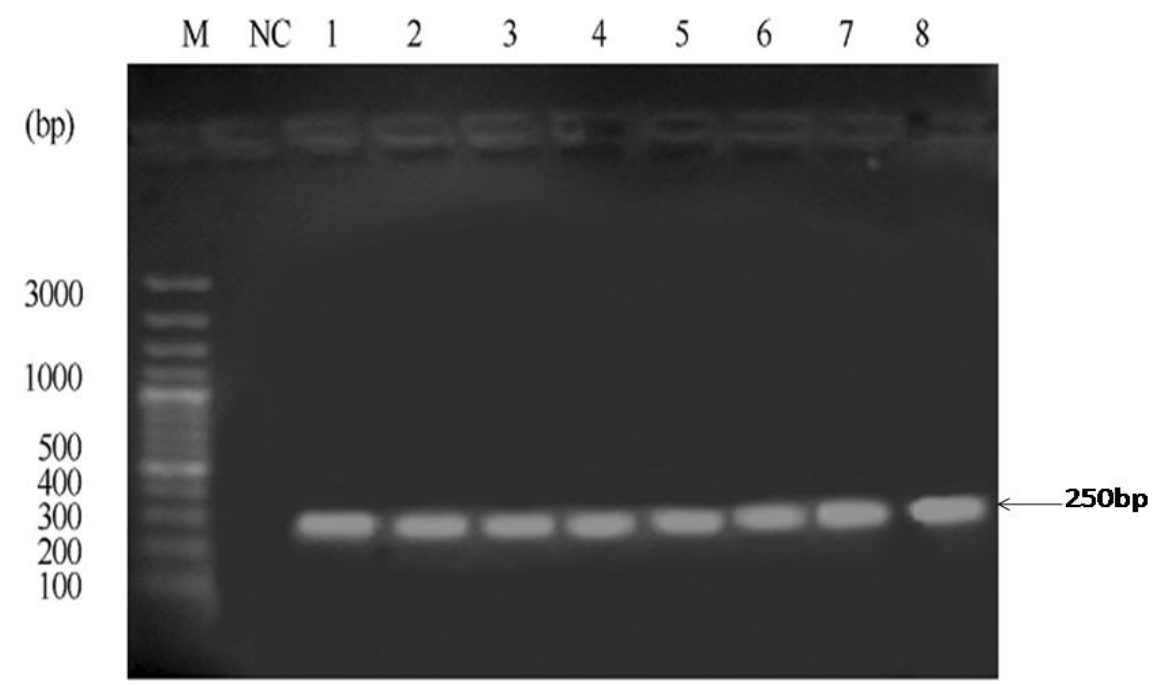

Figure 1. PCR analysis of Lactobacillus. Lane M: DNA marker of $3000 \mathrm{bp}$, Lane NC: negative control, lanes 1-8 indicate the bands for LAA gene (250 bp)

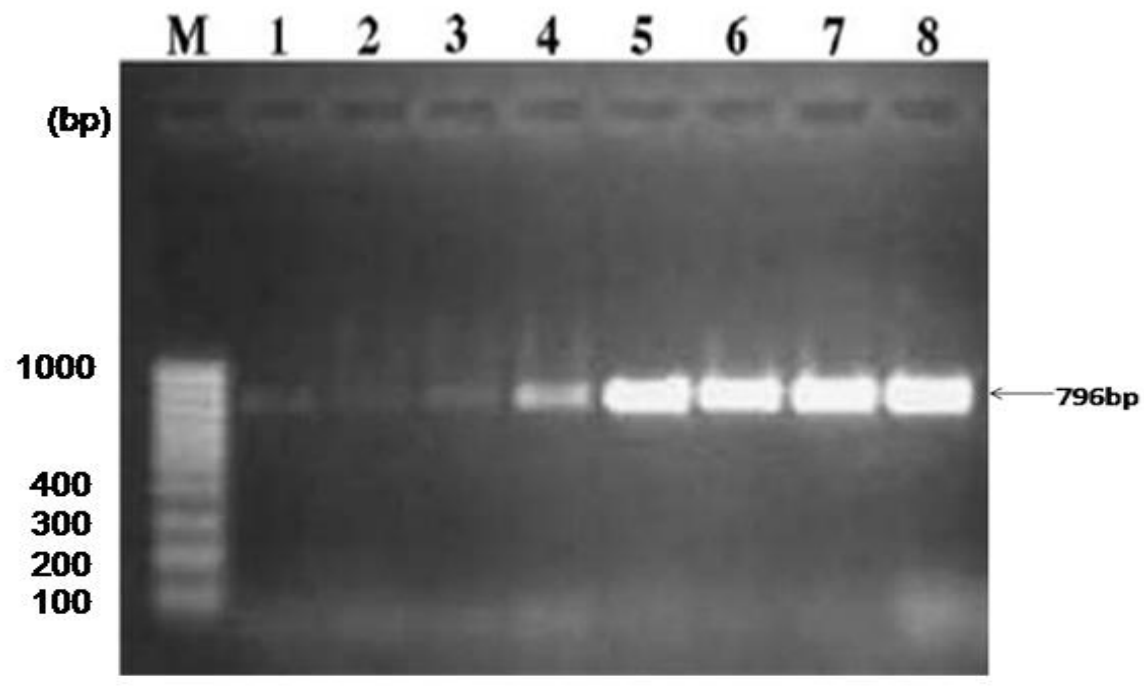

Figure 2. PCR analysis of Salmonella. Lane M: marker of 1kb, Lane 1: positive sample, lanes 2: negative control, 3-8 indicate samples showing bands for InvA gene (796 bp) of Salmonella 


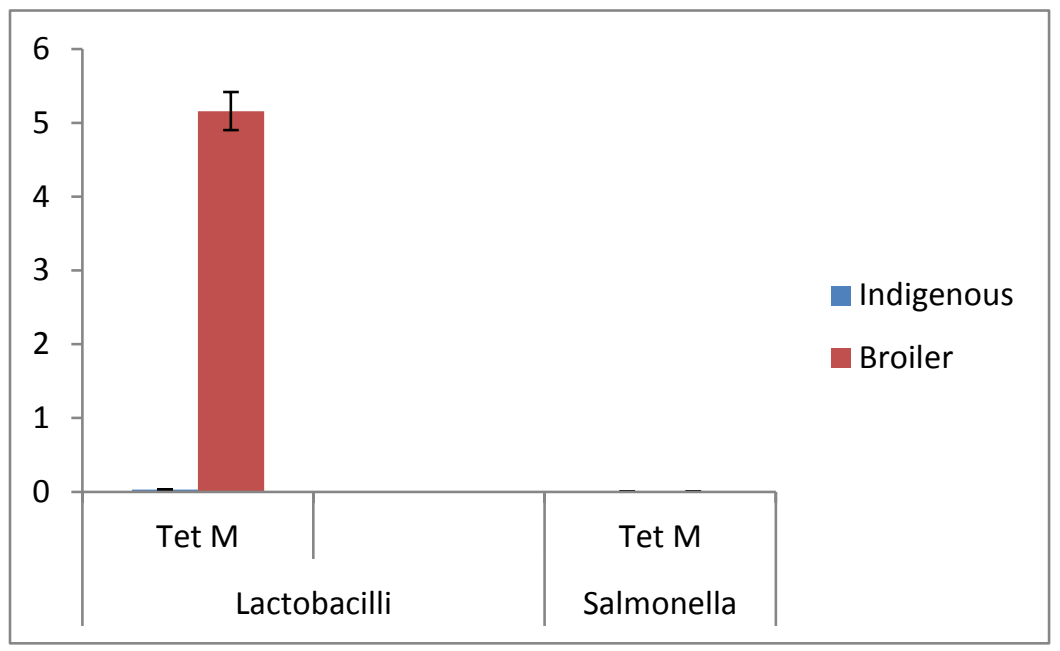

Figure 3.tet $\mathrm{M}$ gene expression level in indigenous and broiler samples

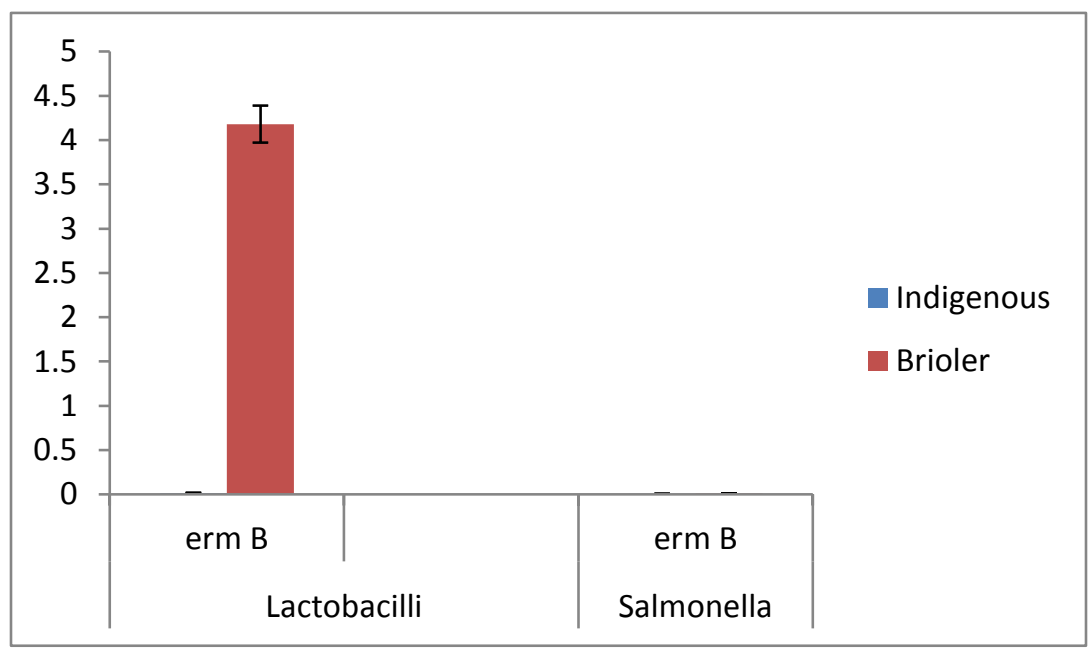

Figure 4.ermB gene expression level in indigenous and broiler samples

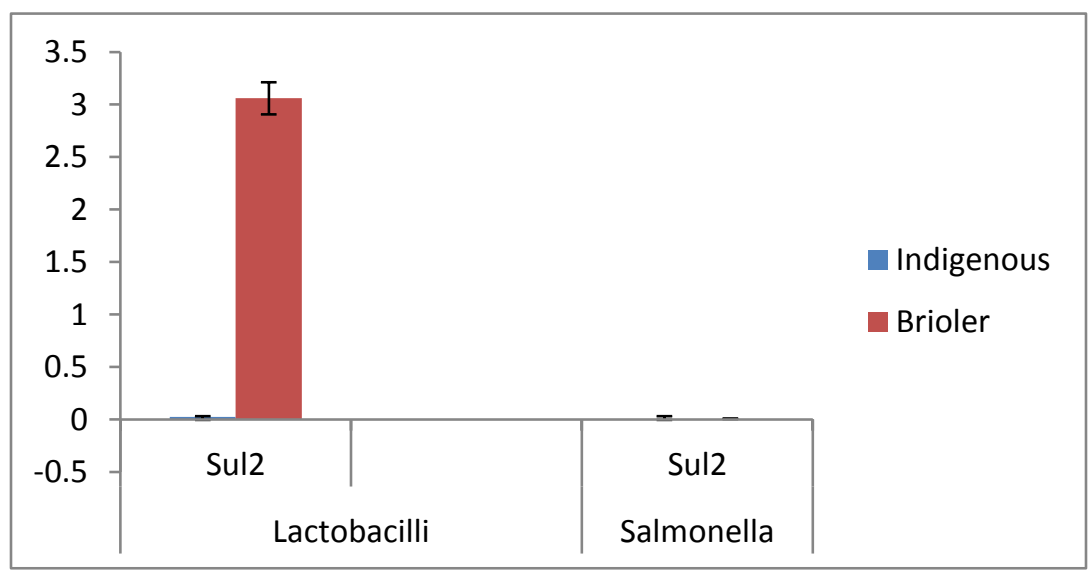

Figure 5. Sul2 gene expression level in indigenous and broiler samples 


\section{Conclusion}

It is concluded that the excessive use of animal growth promoters in poultry assists in acquisition of antibiotic resistance genes by normal micro-biota and hence, development of antibiotic resistance in these strains. The study may assist to offer the future aspects to discover the potential role of horizontal transmission of antibiotic resistance genes from Lactobacillus to other pathogenic bacteria.

\section{Authors'contributions}

Conceived and designed the experiments: $\mathrm{M}$ Ashraf \& R Aslam, Performed the experiments: $M$ Ashraf, Analyzed the data: $S$ Ali, Contributed reagents/ materials/ analysis tools: S Ali, Wrote the paper: S Anam \& FR Anjum.

\section{Acknowledgement}

The author would like to thank all the coauthors and laboratory staff for their contribution.

\section{References}

1. Chai SJ \& Mahon B (2011). Memorandum torecord: Foodborne illness from Salmonella and Campylobacter associated with poultry. US Department of Health and Human Services Washington, D.C.

2. Scallan E, Hoekstra RM, Angulo FJ, Tauxe RV, WiddowsonMA, Roy SL, Jones JL \& Griffin PM (2011). Foodborne illness acquired in the United Statesmajor pathogens. Emerg Infect Dis 17(1): 7.

3. Chopra I \& Roberts M (2001). Tetracycline antibiotics: Mode of action, applications, molecular biology, and epidemiology of bacterial resistance. Microbiol Mol Biol Rev 65: 232-260.

4. Antunes P, Machado J, Sousa JC \& Peixe L (2005). Dissemination of sulfonamide resistance genes (sul1, sul2, and sul3) in Portuguese Salmonella enterica strains and relation with integrons. Antimicrob Agents Chemother 49(2): 836-839.

5. Verraes C, Van Boxstael S, Van Meervenne E, Van Coillie E, Butaye P, Catry B, De Schaetzen MA, Van Huffel X,
Imberechts H, Dierick K \& Daube G (2013). Antimicrobial resistance in the food chain: a review. Inter $J$ Environ Res Pub Health10(7): 2643-2669.

6. Catry B, Croubels S, Schwarz S, Deprez P, Cox B, Kehrenberg C, Opsomer G, Decostere A \& Haesebrouck F (2008). Influence of systemic fluoroquinolone administration on the presence of Pasteurella multocida in the upper respiratory tract of clinically healthy calves. Acta Veterinaria Scandinavica 50(1): 36.

7. Depoorter P, Persoons D, Uyttendaele M, Butaye P, De Zutter L, Dierick K, Herman L, Imberechts H, Van Huffel X \& Dewulf J (2012). Assessment of human exposure to 3rd generation cephalosporin resistant E. coli (CREC) through consumption of broiler meat in Belgium. Inter $J$ food Microbiol 159(1): 30-38.

8. Mathur S\& Singh R (2005). Antibiotic resistance in food lactic acid bacteria-a review. Inter J Food Microbiol 105:28195.

9. Aarestrup FM (2006). Antimicrobial Resistance in Bacteria of Animal Origin. $1^{\text {st }}$ Ed. ASM Press; Washington, DC (USA).

10. Burrus V \& Waldor MK (2004). Shaping bacterial genomes with integrative and conjugative elements. Res Microbiol 155: 376-386.

11. Shazali N, Foo HL, Loh TC, Choe DW \& Rahim RA (2014). Prevalence of antibiotic resistance in lactic acid bacteria isolated from the faeces of broiler chicken in Malaysia. Gut Pathog 6(1): 1.

12. Comunian R, Daga E, Dupré I, Paba A, Devirgiliis C, Piccioni, V, Perozzi G, Zonenschain D, Rebecchi A, Morelli L \& De Lorentiis A (2010). Susceptibility to tetracycline and erythromycin of Lactobacillus paracasei strains isolated from traditional Italian fermented foods. Inter J Food Microbiol 138(1-2): 151-156.

13. Phuphisut O, Yoonuan T, Sanguankiat S, Chaisiri K, Maipanich W, Pubampen S, Komalamisra C \& Adisakwattana P 
(2014). Triplex polymerase chain reaction assay for detection of major soiltransmitted helminths,

Ascarislumbricoides, Trichuristrichiura, Necatoramericanus, in fecal samples. Southeast Asian J Trop Med Public Health 45(2): 267.

14. Verweij JJ, Blangé RA, Templeton K, Schinkel J, Brienen EA, van Rooyen MA, Van Lieshout L \& Polderman AM (2004). Simultaneous detection of Entamoeba histolytica, Giardia lamblia, and Cryptosporidium parvum in fecal samples by using multiplex real- time PCR. $J$ Clin Microbiol 42(3): 1220-1223.

15. Zou M, Keelara S \& Thakur S (2012). Molecular characterization of Salmonella entericaserotype Enteritidis isolates from humans by antimicrobial resistance, virulence genes, and pulsed-field gel electrophoresis. Foodborne Pathog Dis 9(3): 232-238.

16. Bokhari DM, Khan H, Riaz MN, Ullah A \& Yunus AW(2017). Probiotic characterization of the Lactobacillus isolates from the gastrointestinal tract of poultry in Pakistan. Pak J Agr Sci 54(4).

17. Zhang L, Kinkelaar D, Huang Y, Li Y, Li X \& Wang HH (2011). Acquired antibiotic resistance: are we born with it?, Appl Environ Microbiol 77(20): 7134-7141.

18. Mustapha A \& Li Y (2006). Molecular detection of foodborne bacterial pathogens. In PCR Methods in Foods 6990.

19. Flórez AB, Alegría Á, Rossi F, Delgado S, Felis GE, Torriani S \& Mayo B (2014). Molecular identification and quantification of tetracycline and erythromycin resistance genes in Spanish and Italian retail cheeses.Bio Med Res Inter.

20. Gevers D, Danielsen M, Huys G \& Swings J (2003). Molecular characterization of
tet(M) genes in Lactobacillus isolates from different types of fermented dry sausage. Appl Environ Microbiol 69(2): 1270-5.

21. Frazzon APG, Gama BA, Hermes V, Bierhals CG, Pereira RI, Guedes AG, d'Azevedo PA \& Frazzon J (2010). Prevalence of antimicrobial resistance and molecular characterization of tetracycline resistance mediated by tet $(\mathrm{M})$ and tet(L) genes in Enterococcus spp. isolated from food in Southern Brazil. World $J$ Microbiol Biotech26(2): 365-370.

22. Thumu SC \& Halami PM (2012). Presence of erythromycin and tetracycline resistance genes in lactic acid bacteria from fermented foods of Indian origin. Antonie Van Leeuwenhoek 102(4): 54151.

23. Jacobsen L, Wilcks A, Hammer K, Huys G, Gevers D \& Andersen SR (2007). Horizontal transfer of tet(M) and erm(B) resistance plasmids from food strains of Lactobacillus plantarum to Enterococcus faecalis $\mathrm{JH} 2-2$ in the gastrointestinal tract of gnotobiotic rats. FEMS Microbiol Ecol 59(1): 158-66.

24. Haarman M \& Knol J (2006). Quantitative real-time PCR analysis of fecal Lactobacillus species in infants receiving a prebiotic infant formula. Appl Environ Microbiol 72(4): 2359-65.

25. Jiang X \& Shi L (2013). Distribution of tetracycline and trimethoprim/sulfamethoxazole resistance genes in aerobic bacteria isolated from cooked meat products in Guangzhou, China.Food control 30(1): 30-34.

26. Bokhari DM, Khan H, Riaz MN, Ullah A \& Yunus AW (2017). Probiotic characterization of the Lactobacillus isolates from the gastrointestinal tract of poultry in Pakistan. Pak J Agr Sci 54(4). 